\title{
Correction to: Genetic characterization and expression analysis of wheat (Triticum aestivum) line 070R1074 exhibiting very low polyphenol oxidase (PPO) activity
}

\author{
S. M. Hystad ${ }^{1}$ ·. M. Martin ${ }^{1}$ - R. A. Graybosch ${ }^{2}$ M. J. Giroux ${ }^{1}$ (i)
}

Published online: 21 October 2019

(c) Springer-Verlag GmbH Germany, part of Springer Nature 2019

\section{Correction to: Theor Appl Genet (2015) 128:1605-1615 https://doi.org/10.1007/s00122-015-2535-8}

The above-mentioned article was published in 2015 with an error in the reverse primer sequence for the PPOA2d1074 marker, which made amplification difficult. The reverse primer was missing a thymine nucleotide at the thirteenth position (GCGGTGCTTCACTTGGT). The corrected marker can be found in the following table. Additionally, a new primer set that provides a shorter, more abundant PCR product was designed and validated. The new marker is designated PPOA2d1074_2.

\begin{tabular}{lllll}
\hline Marker & Gene & $\begin{array}{l}\text { Forward } \\
\left(5^{\prime}-3^{\prime}\right)\end{array}$ & $\begin{array}{l}\text { Reverse } \\
\left(5^{\prime}-3^{\prime}\right)\end{array}$ & $\begin{array}{l}\text { Amplicon } \\
\text { size (bp) }\end{array}$ \\
\hline PPOA2d1074 & Ppo-A2d & $\begin{array}{c}\text { CATCATGTA GCGGTG } \\
\text { CCGCCA }\end{array}$ & $\begin{array}{l}\text { CTTCAC } \\
\text { CTR }\end{array}$ \\
& & GATGG & TTGGT \\
PPOA2d1074_2 & Ppo-A2d & ACTTCA & TCACTTGGT 595 \\
& & CCGACA & ATAGCC \\
& & CTGAC & GATGC \\
\hline
\end{tabular}

Publisher's Note Springer Nature remains neutral with regard to jurisdictional claims in published maps and institutional affiliations.

The original article can be found online at https://doi.org/10.1007/ s00122-015-2535-8.

M. J. Giroux

mgiroux@montana.edu

1 Department of Plant Sciences and Plant Pathology, Montana State University, Bozeman, MT 59717-3150, USA

2 USDA-ARS University of Nebraska, Lincoln, NE 68583, USA 